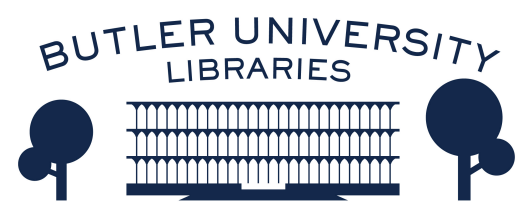

Journal of Hindu-Christian Studies

Volume 23

Article 17

January 2010

\title{
Book Review: "Yoga Body: The Origins of Modern Posture Practice"
}

Harold Coward

Follow this and additional works at: https://digitalcommons.butler.edu/jhcs

Part of the Religion Commons

\section{Recommended Citation}

Coward, Harold (2010) "Book Review: "Yoga Body: The Origins of Modern Posture Practice"," Journal of Hindu-Christian Studies: Vol. 23, Article 17.

Available at: https://doi.org/10.7825/2164-6279.1469

The Journal of Hindu-Christian Studies is a publication of the Society for Hindu-Christian Studies. The digital version is made available by Digital Commons @ Butler University. For questions about the Journal or the Society, please contact cbauman@butler.edu. For more information about Digital Commons @ Butler University, please contact digitalscholarship@butler.edu. 
There is much to be learned from and appreciated in Schouten's Jesus as Guru. However, I was frustrated by phrases such as "Whoever explores the religion and culture of India comes fact to face with a different world," (1) or "...Since then, it is no longer possible to imagine Indian society and culture without Christ." (4) Following an informative intermezzo on Frank Wesley's depiction of Jesus as a blue hued child like Krishna, I wonder why he felt the need to say, "The representation of Jesus is certainly not very accurate historically." (127) These examples, and others, seem to reflect a presumed position of privilege for Caucasian, Western/European, Christian contexts.

While dialogue between "East" and "West" sets the context for the book in the introduction, in the Postscript Schouten acknowledges, “...in the past quarter of a century the voice of Hindus in the dialogue has grown silent." (260) Perhaps future work can assess why this might be so and work to build a new conversation.

Swasti Bhattacharyya

Buena Vista University

\section{Yoga Body: The Origins of Modern Posture Practice by Mark Singleton. Oxford: Oxford University Press, 2010, pp. viii +262 and The Yoga Sutras of Patanjali by Edwin F. Bryant. New York: North Point Press, 2009, pp. 1xvii +598.}

BEFORE tackling Mark Singleton's Yoga Body, one should first read Elizabeth De Michelis' A History of Modern Yoga (Continuum, 2004) where she sets the context for the various forms of modern postural or asana yoga in Vivekananda's lectures on Raja Yoga in 1896 delivered just after the Chicago Parliament of Religions. While Vivekananda purports to be presenting Patanjali's Yoga, he is actually basing his version of Yoga on Keshubchandra Sen along with Theosophy, William James, Krishnamurti and others, and ends up emphasizing mental practice over the physical. Having identified the intellectual root of Modern Yoga as Vivekananda's Raja Yoga, De Michelis shows how in the twentieth century, two developments arise out of Vivekananda, namely Modern Postural Yoga and Modern Meditational Yoga. Mark Singleton studied these historical developments of Yoga together with $\mathrm{De}$ Michelis (also his $\mathrm{PhD}$. supervisor) when the two of them plus Suzanne Newcombe organized the Modern Yoga Graduate Workshop at the Divinity Faculty, University of Cambridge in 2006. Singleton's attention came to be focused on a gap in the development of the Postural Yoga side arising from Vivekananda. While Vivekananda's 1890s Raja Yoga emphasized mental practice and tended to shun the asana or posture side as being unsuitable, Singleton notes that by the 1920 s posture oriented forms of yoga began to re-emerge and dominate. This then is the focus of Singleton's Body Yoga, namely to offer a good explanation of why asana or postural yoga was initially excluded, and to describe the various ways in which it was eventually reclaimed. Body Yoga, says Singleton, "aims to indentify the factors that initially contributed to the shape that transnational yoga has taken today, and constitutes in some ways a 'prehistory' of the international asana revolution that got into full swing with B. K. S. Iyengar and others from the 1950 s onward." Singleton supports this contention by noting that in doing the literature review for Yoga Body, the English language yoga manuals from the late 1800 s to about 1935 largely follow Vivekananda's mental yoga in their approach. In surveying the holdings of Cambridge University Library and the British Library in London, as well as Stanford University's Green Library and the University of California, Berkeley library, Singleton found that the asana or practice oriented Anglophone yoga manual begins to emerge as a genre only during the $1920 \mathrm{~s}$. It is these manuals that 
provide the focus for Singleton's very detailed study. Although Singleton acknowledges that in the post World War II years there was an explosion of interest and publications on yoga, these works were not included in his study - but he does say that they continue to privilege postural over mental yoga.

In the first half of Yoga Body, after a brief overview of yoga in India (especially Hatha Yoga), Singleton examines the figure of the yogin as he appears in travel writing, scholarship, popular culture, and the literature of popular practical yoga in the 1890s. Chapter 2 examines early European encounters with yogins and notes their inferior status during colonial rule, especially hatha yoga practices. In chapter 3 , the author shifts focus to the hatha yogin street performer who does this to earn a living. With the advent of photography, the contortions of the hatha yogin became grist for the Western conception of "exotic India". This along with the downgrading of the posture-practicing yogin by Vivekananda, Blavatsky and others in the late $1800 \mathrm{~s}$ led to the distaste for and exclusion of asana practices in early Western Anglophone yogas. In this way Singleton convincingly explains how postural yoga comes to be so undervalued and little practiced in the anglo world during the years immediately following Vivekananda's Raja Yoga lectures.

Part II of Yoga Body (chapters 4-7) provide a careful and very detailed analysis of the particular modifications hatha yoga had to undergo to escape from being seen as a blight and instead regain a positive perception in the modern West. Chapter 4 examines the late nineteenth and early twentieth century influences of Western physical culture (gymnastics and bodybuilding techniques) introduced into India by organizations such as the Indian YMCA. Chapter 5 shows how during the same period asana yoga traditions began to be combined with Western physical culture practices into a reworked "indigenous" manbuilding that could support the recovery of Indian national pride and counter the colonial perception of Hindu Indians as weaklings. Chapters 6 and 7 consider early twentiethcentury developments of these first experiments in synthesizing yoga and European physical culture. Although in practical Anglophone yoga primers of the first decades of the twentieth century asana remains largely absent, Singleton finds that through these experiments in synthesis asana or postural yoga gradually becomes the most prominent practice component in mainstream modern yoga. Chapter 6 focuses on the contributions of gymnastics and bodybuilding to this nationalist man-building process, while chapter 7 examines the female contributions of spiritualized methods of movement and dance common in women's physical culture classes of the early twentieth century. Chapter 8 identifies the major influence that photographic realism contributed to reversed perceptions of yoga of the body. Finally, in chapter 9 Singleton examines the influential postural forms developed by $T$. Krishnamacharya as a yoga teacher in Mysore during the 1930s and 1940s. Here Singleton agrees with much of Norman Sjoman's earlier analysis which argues that the "godfather" of today's global asana boom is $T$. Krishnamacharya, who evolved his influential postural forms out of the royal gymnastics tradition of the Mysore Palace. ' Singleton's conclusion does not focus on the derivation of specific yoga postures (as Sjoman does) but rather on the powerful synthesis of Western and Indian Modes of physical culture, contextualized within traditional hatha yoga.

For readers of this journal, a sidelight in Singleton's detailed scholarly analysis is the role that some esoteric forms of Christianity played in all of this. Singleton finds, for example, that Mary Eddy Baker's Christian Science ideas of the power of positive thinking to actuate the diversity in the world found their way into practical yoga manuals during the first half of the twentieth century (p. 130). New Thought together with movements like theosophy and New England Transcendentalism also played a role in bridging between institutional Christianity and the development of popular postural yoga.

Yoga Body, with its focused and careful scholarship, is an excellent contribution to our understanding of how asana yoga evolved in the decades after Vivekananda and became the basis for much of the postural yoga experienced in 
Anglophone culture today. It will be a particularly valuable resource for graduate students wanting to do research on today's modern yoga in relation to its Indian roots. I especially appreciate Singleton's careful avoidance of the temptation to treat Patanjali's Yoga Sutras or classical hatha yoga texts as the "gold standard" against which modern yoga may be compared and criticized for its divergences. The author rejects such essentialist textural approaches and instead engages in a scholarly study of the synthesis instead of hatha yoga with various western influences and an open analysis of the resulting modern forms of postural yoga.

By contrast, Edwin Bryant's book does take The Yoga Sutras of Patanjali along with its commentaries and scriptural antecedents as the key text upon which to focus. What Bryant offers is nothing less than a new edition, translation and commentary of the foundational text of the Yoga School of Classical Indian Philosophy. My teacher, Professor T. R. V. Murti, with whom I read the Yoga Sutras in traditional line by line guru-sishya style, used to say that the student's responsibility was not just to pass on the teachings of a tradition or line of teachers (guru-parampare) but to add to it by bringing out new insights. In his book, Bryant succeeds in making just such a contribution in the Commentary he produces which is both easy to read for today's students and offers scholars a distinctive interpretation that Bryant draws from the traditional commentaries, especially that of Vijnanabhiksu, (along with quotes from the Upanisads, Gita and illustrative stories drawn from his own translation of the Bhagavata Purana). What Bryant does most effectively is to place the teaching of Patanjali in the context of the Hindu, Buddhist and Jain thinking of his day and at the same time to make it relevant to the struggle with comsumerism, technology and sensory gratification that dominate society today. As Bryant puts it, while modern societies no longer sacrifice animals to the gods, recite Vedic hymns or pour ghee into the fire in order to obtain material goods, the difference is mainly that today we use different machinebased industrial technologies in our attempt to satisfy ourselves with material goods. "Our modern world has universalized, idolized and mass-produced consumerisms - the indulgence of the senses and the mind - as the highest and most desirable goal of life." (p. xvii) Yet as the Gita tells us, desire is never satisfied and burns like fire - it is the internal enemy that destroys people. This insight, says Bryant, is found in the ancient Hindu, Buddhist and Jaina thought. They all taught that the more we desire, the more we are frustrated, and the more we strive to satisfy this frustration, the more we damage ourselves and our environment. What Patanjali offers in his systemization of this ancient teaching is a clear critique of the mind-set of consumption and an alternative way to live that remains as relevant for today as it was for Indian society in Patanjali's time (c. $200 \mathrm{CE}$ ). But it is a solution that requires gaining control over the mind and its desires - the main focus of Patanjali's yoga practice. As Bryant puts it, "an abandonment of the consumer mentality requires the full eight limbs of yoga, beginning with the yamas and nujamas. Without these, attempts to perfect the third limb of yoga, asanas, postures, are simply physical gymnastics." (p. xvii)

Equating yoga practice with physical postures alone (as Singleton's Yoga Body shows is often the modern experience) misses the whole point of Patanjali's approach - especially if done with the view to improve the sensual prowess and appearance of the body in order to maximize physical and mental pleasure. Bryant concludes, "Without recognizing the actual goal of yoga, the realization of the true self as other than the body, mind, and sensual apparatus, modernity may not have progressed in attitude and presupposition concerning life's goals from those lusty performers of Vedic sacrifice." (p. $\mathrm{xvii)}$

In reading the Yoga Sutras with Professor Murti, I learned that in contrast to the monism of Advaita Vedanta, Patanjali's sutras were dualistic, seeing purusa and prakriti as distinct realities. In his Commentary, Bryant has convinced me that this understanding of the Sankhya-Yoga school was likely a later development when the six astika schools of Hindu philosophy and the various Buddhist schools developed canons of thought far more rigid than was likely the case at the time of Patanjali. Bryant's opening History of Yoga and 
his introduction to his Commentary skillfully immerses one into the intellectual context of Patanjali's time: Rather than rigid separation into specific schools, each with their own doctrine and way of realizing release of moksa, Bryant convincingly suggests that during the centuries leading up to and immediately following Patanjali, thinkers drew broadly from a common pool of ideas including the Upanisads, Gita, Puranas, as well as Jaina and Buddhist thought and a variegated group of practices going by the name yoga. Thus, in his systemization of yoga in the Yoga Sutras, Patanjali sieved this pool of ideas for a psychology of the mind and a technique for extracting the atman or purusa from the mind's materialistic mancinations so that moksa or freedom from rebirth could be realized. While Patanjali's Yoga Sutra systemization is in explicit opposition to Vedic ritualism, according to Bryant, it does not reject the underpinning of the external world as the Upanisadic Brahman, localized in living beings as atman or purusa. Much is drawn from the Gita's Chapter 6 description of yoga as a practice to purify the atman. Patanjali includes many of the Gita yoga practices in his list of yamas and niyamas, including meditation upon and dedication to the God - Isvara-pranidhana (Sutra 1:23) which leads Bryant to conclude that the Yoga Sutras is an inherently theistic text (here he agrees with Ian Whicher who made the same argument earlier in his 1998 book, Integrity of the Yoga Darsana). ${ }^{2}$ Seeing the Yoga Sutras as inherently theistic is also a challenge to my teaching from Murti, but after reading Bryant's fine extended seven page commentary on sutra 1:23 Isvarapranidhana I am convinced. Christian scholars will also find this passage of interest for it is one of the only sutras where the "pull yourself up by your own self-discipline" approach gives way to divine grace. (p. 81-7)

Going back to the issues of the place of physical postures, Bryant makes clear that in both the pre- Patanjali background and in Patanjali's own systemalization there are few references to asana or posture. Of the nine hundred references to yoga in the Mahabharata, there are only two mentions of asana. Neither the Upanisads nor the Gita speaks of posture in the sense of stretching exercises or bodily poses but rather as a physical seat. Patanjali dedicates only three of 195 sutras to this aspect of the practice - the purpose of asana being to keep the body still so that it cannot rush here and there after material and sensuous desires. Also, a controlled and quiet body supports the majority of Patanjali's practices that aim at bringing the distracted and grasping mind under control. In relation to the modern postural yoga traditions studied in Singleton's Yoga Body, Bryant observes that "the perception of yoga as primarily...asana in the sense of bodily poses...is essentially a modern Western phenomenon and finds no precedent in the premodern yoga tradition..." (p. xxx)

Both of the books offer excellent, user friendly, but serious scholarship suitable for graduate and senior undergraduate students. The works of De Michelis and Singleton offer the best analysis of modern yoga teaching and practice while Bryant's translation, Commentary and Introduction to Patanjali's Yoga Sutras is now my book of choice for serious senior students. Bryant's book serves as both a concordance of commentaries and a commentary on key scriptures and commentaries without which the Yoga Sutra are unintelligible. After Bryant I would then send the student to Yoga: India's Philosophy of Meditation (Vol. XII of the Encyclopedia of Indian Philosophies) edited by Gerald Larson as the basic reference text for Patanjali's Yoga Sutras and the classical Yoga School. $^{3}$

\section{Notes}

1. Norman E. Sjoman, The Yoga Tradition of the Mysore Palace. New Dehli: Abhinav, 1996.

2. It is of interest to note that Whicher, De Michelis and Singleton all did their yoga research at the Cambridge Faculty of Divinity with Julius Lipner playing a guiding role.

3. Yoga: India's Philosophy of Meditation. Edited by Gerald James Larson and Ram Shankar Battacharya. Dehli: Motilal Banarsidass, 2008.

Harold Coward

University of Victoria 